\title{
EFFECT OF STAGE OF GROWTH AND ADDITIVES ON DIGESTIBILITY AND PALATABILITY OF GUINEA (PANICUM MAXIMUM,JACQ) GRASS SILAGE
}

\author{
SUJATHA PREMARATNE, M.N.M. IBRAHIM AND H.G.D. PERERA \\ Department of Animal Science, Faculty of Agriculture, University of Peradeniya, Peradeniya.
}

\author{
(Date of receipt : 25 June 1991) \\ (Date of acceptance : 15 June 1993)
}

\begin{abstract}
Experiments were conducted to investigate the digestibility and palatability of Guinea-'A' (Panicum maximum, Jacq) grass silage by sheep. One month growth of Guinea was harvested and ensiled directly whereas, mature Guinea (8 weeks) was chopped into half and ensiled alone or with $5 \%$ coconut (Cocos nucifera, L) meal, wet basis or with $5 \%$ rice (Oryza sativa) bran, wet basis in 210 litre metal drums. Animals with an initial weight of $16.4 \pm 2.5 \mathrm{Kg}$ were used and faeces were collected by means of light. harness and canvas bag. Addition of coconut meal at the time of ensiling increased $(P<0.05$ ) crude protein content of silage compared to mature silage without additives. Digestibility of dry matter, organic matter and crude protein were higher $(P<0.05)$ for one month old Guinea grass silage and silage prepared with the addition of coconut meal compared to other two treatments. Addition of coconut meal at the time of ensiling also increased $(P<0.05)$ the dry matter and organic matter intake of silage by sheep. The data indicate that the nutritive value and intake of silage prepared from mature, chopped Guinea grass with $5 \%$ coconut meal, wet basis was similar to that of silage prepared from 1 month old Guinea grass.
\end{abstract}

Key words : Guinea grass, silage, additives, digestibility, palatability, growth stage.

\section{INTRODUCTION}

Silage making is not a common practice in tropical countries. However, silage has been made with varying success and with varying capital outlay in towers, clamps, pits and trenches in Government Agricultural Stations. Several research workers have reported the characteristic features of silage made from tropical herbage plants.$^{14}$ According to these workers, the factors eg. lactic acid, $\mathrm{pH}$, concentration of $\mathrm{NH}_{3}$ and butyric acid that may be responsible for preserving of tropical silage have not been established. However, they have concluded that this process is not related with the production of high concentration of lactic acid. ${ }^{14}$

It is common knowledge that the digestibility of forage decreases with the maturity in tropical forages. It is also interesting to note that the chopping increased the digestibility and voluntary feed intake of temperate forage silage by sheep. ${ }^{5-9}$ Published information on the effect of stage of growth and additives on digestibility and palatability of tropical grass silage is lacking. The objective of this study was to investigate the effect of stage of growth and additives on digestibility and palatability of Guinea - 'A' grass (Panicum maximum, Jacq) silage to sheep. 


\section{METHODS AND MATERIALS}

\section{Preparation of Silage}

An established stand of Guinea ' $A$ ' grass from the Veterinary Research Institute, Gannoruwa, longitude $80^{\circ} 29^{\prime} \mathrm{E}$, latitude $7^{0} 13^{\prime} \mathrm{N}$, elevation $485 \mathrm{~m}$ was used. The forage was harvested at two periods viz., 1 month after foliage regrowth and after flowering (8 weeks). The herbage was handcut to $12.5 \mathrm{~cm}$ above ground level. The forage harvested at 1 month after foliage regrowth (about $30 \mathrm{~cm}$ in length) was ensiled alone (Treatment 1) whereas forage harvested after flowering was chopped into half (about $45 \mathrm{~cm}$ in length) and divided into 3 equal portions. One portion of the material was ensiled alone (Treatment 2) and the other two portions were ensiled either with 5\% coconut (Cocos nucifera, L) meal, wet basis (Treatment 3) or with 5\% rice (Oryza sativa) bran, wet basis (Treatment 4). Several samples of the grass were taken while filling each silo for subsequent analysis. The grass for ensiling was firmly packed into 210 litre steel drums double lined with $0.08 \mathrm{~mm}$ (1000 gauge) polyethylene bags. An attempt was made to remove as much air above the ensiled mass as possible before each polyethylene bag was sealed. The bags were sealed with plastic coated wire and the drums were stored upright in an open barn from harvest until the initiation of sheep feeding trials (about 2 months).

\section{Digestibility Studies}

An experiment was conducted with ten sheep (about 4-5 months of age) with an initial weight of $16.4 \pm 2.5 \mathrm{Kg}$. The experiment consisted of two periods, at each period the sheep were placed in three blocks by weight. Sheep within each block were allocated at random to the silages with restriction that no animal would receive the same silage in both periods. The allocation was in a such way that in period 1, treatment's 1 and 2 had three animals each and treatment's 3 and 4 had two animals each. In period 2, treatment's 1 and 2 had two animals each and treatment's 3 and 4 had three animals each. As such, at the end of two periods, five individual animal data were obtained for each treatment. The design used was an incomplete randomized block design.

All sheep were treated for internal parasites with 'Nilworm'. The sheep were fed the silages and $55 \mathrm{~g}$ of mineral-vitamin mixture twice daily (6 and $18 \mathrm{~h})$ in equal amounts. Silages and water were provided ad-libitum. The sheep were housed in individual 1.22 $\times 1.07 \mathrm{~m}$ stalls in a semi-closed barn. Each period consisted of a 14 day preliminary followed by a 7 day measurement period. Canvas bags held by harnesses as described by Fontenot and Hopkins ${ }^{10}$ were used to collect faeces. Beginning 2 days before the start until 2 days prior to the end of the 7 days collection period, the silages were sampled at each feeding. The silage samples were frozen daily in doubled plastic bags and composited at the end of the period. Refusals and faeces were collected twice daily and dried at $55^{\circ} \mathrm{C}$ to a constant weight for dry matter determination, allowed to air equilibrate, then ground to pass through a $1 \mathrm{~mm}$ screen. Kjeldhal nitrogen was determined on faeces, refusals and silage samples. ${ }^{11}$ All samples were analysed for dry matter (DM), neutral detergent fibre (NDF), ${ }^{12}$ acid detergent fibre (ADF), ${ }^{13}$ lignin 
and cellulose. ${ }^{14}$ All animals were weighed before and after the period. The average of the initial and final weights was used to determine metabolic size $\left(\mathrm{W}^{0.75} \mathrm{~kg}\right)$ on which dry matter intake was calculated.

\section{Statistical Analysis}

Statistical analysis were performed using the analysis of variance procedure for an incomplete randomized block design ${ }^{15}$ and treatments were compared using least significant difference values.

\section{RESULTS}

Table 1 presents the composition of Guinea grass, coconut meal and rice bran used in the preparation of silage. Crude protein and water soluble carbohydrate content of coconut meal were very much higher whereas, NDF, ADF, lignin and silica were lower compared to grasses and rice bran used in the preparation of silages. Crude protein content of 1 month Guinea grass was much higher whereas cell wall fractions were lower compared to 2 month Guinea grass. The composition of silage fed in sheep digestibility experiment is shown in Table 2. Addition of coconut meal at the time of ensiling increased $(P<0.05)$ the crude protein content of silage when compared with the mature silage without additives $(8.2 \%$ vs $6.2 \%)$. However, there was no significant difference between the 1 month old Guinea grass silage and silage prepared with the addition of coconut meal.

Table 1: Composition of Guinea grass, coconut meal and rice bran (\% of dry matter) used in the preparation of silage.

\begin{tabular}{lccrr}
\hline \multicolumn{1}{c}{ Component } & \multicolumn{2}{c}{ Guinea grass } & $\begin{array}{c}\text { Coconut } \\
\text { meal }\end{array}$ & Rice bran \\
& 1-month & 2-months & & \\
\hline Dry matter & 91.5 & 93.0 & 86.0 & 87.4 \\
Crude protein & 14.1 & 7.8 & 23.1 & 9.5 \\
Ether extract & 2.3 & 2.3 & 10.9 & 1.5 \\
Cell wall fractions : & & & & \\
NDF & 74.7 & 80.8 & 48.9 & 56.2 \\
ADF & 48.4 & 52.6 & 29.9 & 47.4 \\
Cellulose & 34.4 & 41.2 & 24.7 & 23.1 \\
Hemicellulose & 26.3 & 28.2 & 19.0 & 8.8 \\
Lignin & 10.1 & 11.5 & 4.9 & 11.5 \\
Ash & 10.1 & 9.8 & 7.2 & 21.5 \\
Silica & 3.8 & 4.7 & 0.9 & 10.8 \\
Water soluble carbohydrates & 4.9 & 6.1 & 12.7 & 7.0 \\
\hline
\end{tabular}

NDF - neutral detergent fibre

ADF - acid detergent fibre 
Table 2: Composition and cell wall fractions of silage fed in sheep digestibility and palatability trials (\% of dry matter) ${ }^{\mathrm{a}}$.

\begin{tabular}{|c|c|c|c|c|}
\hline \multirow[t]{3}{*}{ Component } & \multicolumn{4}{|c|}{ Growth period } \\
\hline & 1-month & & 2-months & \\
\hline & No additives & No additives & With coconut meal & With rice bran \\
\hline Dry matter & $92.7^{b}$ & $94.9^{c}$ & $95.9^{c}$ & $94.4^{c}$ \\
\hline Crude protein & $8.9^{\mathrm{d}}$ & $6.2^{\mathrm{b}}$ & $8.2^{c, d}$ & $7.6^{c}$ \\
\hline \multicolumn{5}{|c|}{ Cell wall fractions } \\
\hline NDF & $67.5^{b}$ & $71.9^{c}$ & $68.0^{b}$ & $66.8^{b}$ \\
\hline ADF & 52.0 & 54.4 & 50.7 & 51.5 \\
\hline Cellulose & $36.8^{c, d}$ & $37.8^{d}$ & $35.9^{b, c}$ & $34.9^{\mathrm{b}}$ \\
\hline Hemicellulose & 15.5 & 17.5 & 18.8 & 15.3 \\
\hline Lignin & 10.5 & 11.0 & 8.9 & 10.0 \\
\hline
\end{tabular}

Dry basis

Different superscripts in a row are significantly different $(P<0.05)$.

Dry matter and organic matter intake of silage per metabolic body weight of sheep were much higher $(\mathbf{P}<0.05)$ for silage prepared with coconut meal compared to other three treatments (Table 3 ). Table 4 presents the digestibility of Guinea - ' $A$ ' silage by sheep. Digestibility of dry matter, organic matter and crude protein were higher $(\mathrm{P}<0.05)$ for 1 month old Guinea grass silage compared to mature grass silage without additives. Furthermore, digestibility of dry matter, organic matter and crude protein were higher $(P<0.05)$ for 1 month old grass silage and silage prepared with the addition of coconut meal compared to other two treatments ( 2 month old grass silage control and 2 month old grass silage with rice bran). Addition of coconut meal at the time of ensiling increased $(P<0.05)$ the organic matter digestibility of the ensiled product by 4.5 digestibility units compared to mature silage without additives. However, addition of coconut meal at the time of ensiling increased $(P<0.05)$ the crude protein digestibility of the ensiled product by 9.7 digestibility units compared to the mature grass silage without additives. Addition of rice bran at the time of ensiling decreased $(P<0.05)$ the dry matter and organic matter digestibility of silage compared with mature grass silage without additives (Table 4). Addition of rice bran at the time of ensiling also decreased $(P<0.05)$ the digestibility of cell wall fractions. 
Table 3: Dry matter and organic matter intake of sheep fed Guinea - 'A' silage."

\begin{tabular}{|c|c|c|c|c|}
\hline \multirow[t]{3}{*}{ Component } & \multicolumn{4}{|c|}{ Growth period } \\
\hline & 1-month & & 2-months & \\
\hline & No additives & No additives & With coconut meal & With rice bran \\
\hline \multicolumn{5}{|c|}{ Dry matter intake } \\
\hline g/day & $497^{b}$ & $516^{b, c}$ & $602^{\mathrm{d}}$ & $571^{c, d}$ \\
\hline $\mathrm{g} / \mathrm{W}^{0.75} \mathrm{~kg} /$ day & $60^{b}$ & $61^{b}$ & $68^{c}$ & $66^{b, c}$ \\
\hline \multicolumn{5}{|c|}{ Organic matter intake } \\
\hline g/day & 437 & 450 & 527 & 492 \\
\hline $\mathrm{g} / \mathrm{W}^{0.75} \mathrm{~kg} /$ day & $53^{b}$ & $53^{b}$ & $59^{c}$ & $57^{b, c}$ \\
\hline
\end{tabular}

Mean of five animals.

Different superscripts in a row are significantly different $(\mathbf{P}<0.05)$.

Table 4: Digestibility co-efficients of Guinea - 'A' silage (\%) ${ }^{\mathrm{a}}$.

Component

1-month
Growth period

2-months

No additives No additives With coconut meal With rice bran

\begin{tabular}{lllll}
\hline Dry matter & $51.5^{\mathrm{d}}$ & $45.2^{\mathrm{c}}$ & $50.8^{\mathrm{d}}$ & $42.3^{\mathrm{b}}$ \\
Organic matter & $55.7^{\mathrm{d}}$ & $51.3^{\mathrm{c}}$ & $55.8^{\mathrm{d}}$ & $48.2^{\mathrm{b}}$ \\
DOMD('D' value) & $48.9^{\mathrm{d}}$ & $44.7^{\mathrm{c}}$ & $48.8^{\mathrm{d}}$ & $41.5^{\mathrm{b}}$ \\
Crude protein & $52.8^{\mathrm{d}}$ & $44.5^{\mathrm{b}}$ & $54.2^{\mathrm{c}}$ & $45.1^{\mathrm{b}}$ \\
Cell wall fractions: & & & & \\
NDF & $50.3^{\mathrm{d}}$ & $45.4^{\mathrm{c}}$ & $47.5^{\mathrm{c}, \mathrm{d}}$ & $34.7^{\mathrm{b}}$ \\
ADF & $48.3^{\mathrm{d}}$ & $40.4^{\mathrm{c}}$ & $48.3^{\mathrm{d}}$ & $26.3^{\mathrm{b}}$ \\
Cellulose & $60.0^{\mathrm{c}, \mathrm{d}}$ & $57.0^{\mathrm{c}}$ & $63.2^{\mathrm{d}}$ & $49.2^{\mathrm{b}}$ \\
Hemicellulose & $65.7^{\mathrm{c}}$ & $58.9^{\mathrm{b}}$ & $64.3^{\mathrm{c}}$ & $57.1^{\mathrm{b}}$ \\
\hline
\end{tabular}

- Mean of five animals

Different superscripts in a row are significantly different $(P<0.05)$.

\section{DISCUSSION}

Addition of coconut meal and rice bran at the time of ensiling increased the crude protein content of silage compared with mature silage without additives. This increase in crude protein content is associated with the higher crude protein content of these additives (Table 1). Dry matter and organic matter intake of silage with coconut meal was higher compared to 1 month and 2 month grass silage without additives (Table 3). However, there was no difference in intake between silages with coconut meal and rice bran. This may be due to the better fermentation improving the palatability of these silages. The intake of mature forage silage without additives was almost similar to that of unchopped 
1 month old silage. This seems surprising in view of the effect of stage of maturity on the fermentation quality of silage. However, Anderson ${ }^{5}$ has shown that there was no significant effect of stage of maturity on silage intake by sheep. According to Table 4, digestibility of dry matter, organic matter, crude protein and cell wall fractions were higher for 1 month old Guinea grass silage compared to mature grass silage without additives. It is generally accepted that the digestibility of forage decreases with increased maturity. ${ }^{2,16,17}$ Digestibility of dry matter, organic matter and crude protein were higher for 1 month old grass silage and silage prepared with the addition of coconut meal compared to other two treatments ( 2 month old grass silage control and 2 month old grass silage with rice bran). The increased digestibility after adding coconut meal during ensiling may be due to improved fermentation. The crude protein content of coconut meal may also increase nitrogen available for microbial growth that in turn may improve the digestibility.

In conclusion, the results presented here indicate that the stage of maturity of the forage significantly affect the digestibility of silage but had no effect on the voluntary feed intake. Furthermore, addition of coconut meal at the time of ensiling increased the digestibility of silage. The data indicate that the nutritive value and intake of silage of mature, chopped Guinea grass with $5 \%$ coconut meal, wet basis, was similar to that of silage prepared from 1 month old unchopped Guinea grass.

\section{Acknowledgement}

We thank the Veterinary Research Institute for supplying grass, Chandra Unawatune for assistance with chemical analysis and A.L. Badurdeen for statistical analysis. This work was supported by a grant from the Natural Resources, Energy and Science Authority of Sri Lanka.

\section{References}

1. Catchpoole V.R. \& Henzell, E.P. (1971). Silage and silage making from tropical herbage species. Herbage Abstracts 41: 213-221.

2. Panditharatne S. (1984). Ensiling characteristics, digestibility and palatability of tropical grasses as affected by growth stage, chopping length and additives. Ph.D. Dissertation, Virginia Polytechnic Institute and State University, VA.

3. Tosi H. (1973). Ensilage de Gramineas tropicais sob differentes tratamentos. Ph.D. Dissertation, Estado de Sao Paulo, Brazil.

4. Xande A. (1978). L'ensilage d'herb, une technique de conservation dl'herbe permettant depallier au deficit alimentaire des ruminants durant la periode du caremeo 1. Aspects theorique et pratique-particularite des fourrage (Ensilage of grass, a conservation technique for obviating the food shortage of ruminants during the dry season. 1. Theoretical and practical aspects particularities of 
tropical forages). Journal Nouvelles Agronomiques des Antilles et de la Guyane. 2: $63-80$.

5. Anderson R. (1982). Effect of stage of maturity and chop length on the chemical composition and utilization of formic acid-treated ryegrass and formic acid silage by sheep. Grass and Forage Science 27:139-145.

6. Deswysen A., Vanebelle M., \& Focant M. (1978). The effect of silage chop length on the voluntary intake and ruminant behavior of sheep. Journal of the British Grassland Society. 33: 107-115.

7. Dulphy J.P. \& Demarquilly C. (1973). Influence de la machine de recolte et de la finesse de hachage sur la valeur alimentaire des ensilage. (Influence of harvesting machine and chop length on the alimentary value of silage). Annals Zootechnie 22: 199-217.

8. Dulphy J.P. \& Michalet B. (1975). Influence comparee de la machine de recolte sur le quantities d'ensilage ingerees par de genisses et des moutons. (Comparative effect of harvesting machine on silage intake by heifers and sheep). Annals Zootechnie. 24:757-763.

9. Thomas P.S., Kelly N.C. \& Wait M.K. (1976). The effect of physical form of a silage on its voluntary composition and digestibility by sheep. Journal of the British Grassland Society 31: 19-22.

10. Fontenot J.P. \& Hopkins H.A. (1965). Effect of physical form of different parts of lamb fattening rations on feedlot performance and digestibility. Journal of Animal Science. 24(1):62.

11. Association of Official Analytical Chemists. (1980). Official Methods of Analysis (12th ed.) Washington D.C.

12. Van Soest P.J. \& Wine R.H. (1967). Use of detergent in the analysis of fibrous feeds. IV. The determination of plant cell wall constituents. Journal of the Association of Official Analytical Chemists. 50: 50-55.

13. Van Soest P.J. (1953). The use of detergents in the analysis of fibrous feeds: II.A rapid method for determination of fiber and lignin. Joumal of the Association of Official Analytical Chemists 46: 829-835.

14. Van Soest P.J. \& Wine R.H. (1968). Determination of lignin and cellulose in acid-detergent fibre with Permanganate. Joumal of the Association of Official Analytical Chemists 51: 780-785.

15. Steel R.G.D. \& Torrie J.R. (1960). Principles and Procedures in Statistics. McGraw Hill, New York. 
16. Devendra (1977). Studies in the intake and digestibility of two varieties (Serdang and Coloniao) of Guinea grass (Panicum maximum) by goats and sheep. Mardi Research Bulletin 5(2):110-121.

17. Peris, H. (1985). Management practices to improve the yield and nutritive value of unfertilized Panicum maximum (Eco type A) in mid country wet zone of Sri Lanka. M. Phil. Thesis, Post Graduate Institute of Agriculture, University of Peradeniya, Peradeniya. 